\title{
Relationship Banking in the Residential Mortgage Market? Evidence from Switzerland
}

\author{
Martin Brown $^{a}$ and Matthias Hoffmann ${ }^{b}$
}

JEL-Classification: G21, D14

Keywords: mortgage loans, household finance, relationship banking.

\section{SUMMARY}

We examine to what extent mortgage lending is characterized by strong relationships between banks and their borrowers. Our analysis is based on survey data covering all current bank relations for a sample of 1,481 Swiss households out of which 687 have a mortgage. We document that mortgage borrowers maintain significantly more bank relations than comparable households without a mortgage. However, this does not imply that mortgage relations are loose. Comparing mortgage relations to other bank relations of the same households we find that mortgage relations are used for a broader scope of transactions and are held with banks that are located closer to the household. Examining the heterogeneity of mortgage relations across households, we find that financially sophisticated households are less likely to hold their mortgage with a local bank.

The authors thank an anonymous referee, SJES co-editor Cedric Tille as well as colleagues at the Swiss Institute of Banking and Finance, Christoph Basten, Catherine Koch, Simone Westerfeld and participants at the 2012 International PhD workshop in Finance in Fribourg for valuable comments. We thank Roman Graf for excellent research assistance.

a Swiss Institute of Banking and Finance, University of St. Gallen, email: martin.brown@unisg. ch.

b Swiss Institute of Banking and Finance, University of St. Gallen, email: matthias.hoffmann. f05@hsgalumni.ch 


\section{Introduction}

In most developed economies residential mortgages are the predominant type of bank loans and by far the most important financial liabilities of households. ${ }^{1}$ Switzerland is no exception: The outstanding volume of mortgage loans currently amounts to $145 \%$ of GDP and accounts for $85 \%$ of all domestic bank loans. ${ }^{2}$ Given the importance of mortgage loans for both banks and households it is surprising how little we know about the relations between mortgage lenders and their clients. In this study we examine to what extent mortgage lending is characterized by strong bank-borrower relations, i.e. relations which are longstanding, which are used for a wide range of payment and savings services, and where the household is located close to the bank.

The theory of financial intermediation suggests that relationship banking mitigates information asymmetries between lenders and borrowers (Воот, 2000). In line with this 'information view' of relationship banking, an extensive empirical literature documents the relevance of firm-bank relations in business lending (Kysucky and Norden, 2016). By comparison, there is - to our knowledge - no evidence documenting to what extent households maintain tight relationships with their mortgage lenders and whether such relationships are motivated by concerns over information asymmetries.

We study survey data from Switzerland which provide detailed information on all bank relations for 1,481 households. For each household the survey elicits information on the duration of each bank relation and the scope of financial services it is used for. By matching the location of households to the branch network of all commercial banks we also establish the geographic distance between households and each of their banks. In our empirical analysis we first examine whether households with a mortgage maintain more bank relationships than comparable households without a mortgage. We find that this is the case: On average households with a mortgage are 11 percentage points more likely to have multiple bank relations rather than a single bank relation.

The finding that mortgage holders have more bank relationships does, however, not imply that mortgage relations are loose. Focusing on 470 households which have a mortgage and multiple bank relations we relate the incidence of a

1 Beck et al. (2012) document that over the period 1994 to 2005 household credit amounted to $80 \%$ of bank credit in Canada, $76 \%$ in the USA, $66 \%$ in Australia, $60 \%$ in France and $56 \%$ in the UK. Survey evidence suggests that mortgage debt accounts for $75 \%$ of household debt in the USA (Bucks et al., 2009) and $83 \%$ of household debt in Eurozone (ECB, 2013).

2 According to the publication "Banks in Switzerland" of the Swiss National Bank the total volume of domestic mortgage credit amount to 834 billion CHF at the end of 2012. 
mortgage to the duration, geographical proximity and the scope of each relation. We find that mortgage relations are characterized by a broader scope of payment and savings transactions than non-mortgage bank relations of the same households. Mortgage relations are also held with banks located closer to the household but are not characterized by a longer duration.

Examining the heterogeneity of mortgage relations across household types, we provide evidence that financial sophistication affects mortgage bank choice: Households with high wealth, high education and high financial literacy are less likely to hold their mortgage with a local bank branch. By contrast, we do not find that financially opaque borrowers, e.g. younger and urban households maintain tighter mortgage relations than financially transparent households.

Our findings contribute to the growing empirical literature on credit relationships between households and banks. ${ }^{3}$ Holmes et al. (2007) document the importance of long term relationships for access to secured consumer credit (automobile loans), despite the fact that credit scoring is prevalent in this market. Agarwal et al. (2010) document significant benefits of relationship banking for lenders in the credit card market: They provide evidence that relationship accounts with credit-card borrowers exhibit lower probabilities of default and have higher utilization rates, compared to non-relationship accounts. PURI et al. (2011) examine consumer lending by savings banks in Germany and provide evidence that clients with a prior relationship or a broader relationship scope are less likely to default on loans. Guiso et al. (2013) provide evidence suggesting that households with a stronger relation to their lender are less prone to strategic mortgage defaults. We contribute to this strand of literature by providing empirical evidence on the scope, geographic proximity and duration of mortgage relations, and by examining whether the heterogeneity of mortgage relations across households can be rationalized by information asymmetries between lenders and borrowers.

We also contribute to the marketing literature on the choice of bank relations. Research in this field documents that convenience in terms of proximity and accessibility as well as anticipated service quality are the main drivers of bank choice (Blankson et al., 2007). For the residential mortgage market Devlin (2002a), Lymperopoulos et al. (2006) and Mylonakis (2007) confirm these findings, documenting that existing bank relations have a higher impact on the mortgage bank choice than price. Financial sophistication of households also plays an important role in the choice of bank relations. Devlin (2002b) shows

3 KISER (2002) examines deposit relationships of households in the USA and documents high switching costs, especially for both high-income and well-educated households as well as for low-income and minority households. 
that households with low financial literacy primarily choose their banks based on convenience and recommendations, while service quality, product attributes and fees are more important for financially literate households. We contribute to this literature by examining the heterogeneity of mortgage relations across different households using representative survey data.

\section{Institutional Background}

Between 2003 and 2013 the Swiss mortgage market grew from an outstanding volume of 562 billion CHF to 869 billion CHF. Mortgage lending has expanded rapidly in an environment of increasing home ownership rates, rising house prices and historically low interest rates (BRown and Guin, 2015). Today, mortgage lending amounts to $138 \%$ of Swiss GDP and accounts for $86 \%$ of outstanding domestic credit. ${ }^{4}$ Mortgage lending dominates the domestic lending activities across all types of Swiss banks, accounting for between $83 \%$ (large universal banks) and $95 \%$ (regional savings and cooperative banks) of domestic credit.

The most common types of mortgages in Switzerland are fixed rate contracts with maturities of 5-10 years and adjustable rate contracts indexed to the libor. The demand for fixed rate as opposed to adjustable rate contracts is strongly dependent on interest rate conditions (BASTEN et al., 2015). Historically low interest rates since the financial crisis have led to a strong increase in the share of fixed rate mortgages ( $87 \%$ of outstanding volume in 2013 compared to $67 \%$ in 2003). 5

Swiss mortgage lenders typically set a limit on the loan-to-value (LTV) ratio of $80 \%$ and on the payment-to-income (PTI) ratio of $33 \%$. Hereby, the monthly payment is typically calculated based on the long-term mortgage rates $(5 \%)$ and accounts also for costs of maintenance as well as any amortization due (see Brown and Guin, 2015, for details). Mortgages with a LTV between $80 \%$ and $90 \%$ are rare, while loans with an LTV exceeding $90 \%$ are prohibited by macroprudential regulations. Households may use (second pillar) pension fund and (third pillar) voluntary retirement savings as a downpayment or collateral on their mortgage. Macroprudential regulations stipulate at least a $10 \%$ cash downpayment, but this may be financed by liquidating voluntary retirement savings. Pension fund savings can either be liquidated and used as an additional cash downpayment or pledged as additional collateral on a mortgage. Financial

4 Source: Swiss National Bank

5 Source: Swiss National Bank 
assets of the household (securities) may also be pledged as additional collateral on a mortgage.

Households need to amortize their mortgage only if it has an LTV ratio exceeding $66 \% .{ }^{6}$ However, the amortization of mortgages is discouraged by the favourable tax treatment of mortgage debt: Mortgage interest payments can be deducted from income tax. Home-owners are subject to taxation of "imputed rent" on their property. However, the calculated imputed rent is typically substantially lower than the rental value of the property. Due to the preferential tax treatment of mortgage debt households often partly amortize their debt indirectly by building up (tax exempted) voluntary retirement savings rather than fully paying down their mortgage.

Competition for mortgage clients is strong between Swiss banks. The market in any region of the country is typically served by the two large banks, a stateowned cantonal bank as well as regionally operating savings and cooperative banks. Insurance companies and pension funds also offer mortgages, but cover only a marginal share of the market. ${ }^{7}$

\section{Data and Methodology}

\subsection{Data}

Our analysis is based on a survey of 1,481 households in the German-speaking area of Switzerland. The survey was conducted in spring 2011 and is representative of the underlying population with respect to gender, age and regional distribution. ${ }^{8}$ The survey was conducted using telephone interviews which lasted an average of 15 minutes. Households with weak knowledge of the German language were screened out, implying that Swiss citizens and foreigners with German as

6 Lenders typically distinguish a "first" mortgage with an LTV up to $66 \%$ and a "second" mortgage for the remaining amount above the $66 \%$ LTV ratio. The first mortgage is an interest only mortgage, while the second must be repaid within 15 years or prior to retirement.

7 We exclude mortgages from insurance companies in our analysis as they make up less than $1 \%$ of the observed mortgages.

8 The survey was conducted by GfK, a leading market research firm in Europe. The sample size corresponds to $0.05 \%$ of the targeted population in Switzerland, which is an adequate coverage compared to large surveys in the U.S. or the EU (e.g. the Health and Retirement Study in the U.S. covers about $0.03 \%$ and the Survey of Health, Aging and Retirement in Europe about $0.04 \%$ of the targeted population). Respondents were limited to those with an age of 20-74 years of age, with sufficient German skills to be able to understand the questions, and to the respondents which were not self-employed. 
their mother tongue are oversampled. As a consequence, households who are more likely to own their home and have a mortgage are oversampled.'

The survey was designed to elicit information on the number of bank relationships of each household and the scope of financial services used within each relationship..$^{10}$ In addition, information was gathered on the socioeconomic characteristics (e.g. age, education, household income and wealth), financial literacy ${ }^{11}$, and the geographical location of the household. The definitions of all variables from the survey employed in this study are provided in the Appendix.

The 1,481 households in our dataset report a total of 2,863 bank relations. For each relation we elicit whether the household currently has a mortgage with that bank. In our dataset 687 households (46\%) report that they have a mortgage.

For each bank relation we elicit the duration of the relation and the geographical distance between the household and the nearest branch of the bank. Relation duration is measured by the variable Duration $>10$ years, which is one if the relation was initiated at least ten years prior to the survey. The majority of bank relations have a duration exceeding 10 years $(66 \%) .{ }^{12}$ Geographical proximity between the household and the bank is measured by the variable Distance $\leq 5 \mathrm{~km}$ which is one if the nearest branch of the bank is within a five kilometers travel distance of the household by car. ${ }^{13}$ Two-thirds of the bank-relations in our dataset

9 Foreign citizens make up $23 \%$ of the residential population in Switzerland, but only $10 \%$ of the households in our sample. Even within the sample of surveyed households the incidence of a mortgage is twice as high among Swiss citizens (49\%) than among foreign citizens (24\%) resident in Switzerland.

10 The questionnaire is available upon request.

11 Our measure of financial literacy is based on the answers to three standardized questions on inflation, compound interest and risk diversification (LuSARdi and MitchelL, 2011). BROWN and Graf (2013) provide an analysis of financial literacy among the Swiss population based on the same survey data employed in this study.

12 The survey does not provide information on the exact year a bank relation was established. Instead households are asked whether the relation was more than 10 years old, between 5 and 10 years old or more recent. $18 \%$ of the elicited bank relations have a duration of between 5 and 10 years, while $16 \%$ were established within the past 5 years. Our results are robust to setting the threshold for a long relationship at 5 years instead of 10 years.

13 To establish the geographical distance we match the location of each household with handcollected information on the geographical location of all bank branches in Switzerland. We use data for the network of bank branches in Switzerland as per December 2012. Distance calculations are based on zip code information for both households and bank branches, and computed through the Google maps API. For this purpose we made use of the STATA software and the STATA utilities provided by Adam Ozimek that use the google maps API. Relying on zip codes has the downside that those respondents living in the same code area with bank branches are assigned with a distance of zero $\mathrm{km}$, which is, despite the high density of the urban area and the branch network in Switzerland, not fully accurate. 
are held with banks located within a perimeter of $5 \mathrm{~km}$. The variable Banks close measures at the household level how many banks have a branch within the perimeter of $5 \mathrm{~km}$ of the household. On average the households in our sample have 3 banks in their proximity.

The survey provides detailed information on the scope of each bank relation: For each relation, households were asked whether it is the major bank relation they use for five different financial transactions: Incoming payments such as wages or pensions, Outgoing payments such as the rent or utilities bills, ATM withdrawals, Savings for durable goods and household investments, or Retirement savings. We define the Transaction scope of each bank relation as the sum of these five transaction types. On average, each relation in our dataset is used for 2.2 types of payment and savings transactions. The survey also provides information on the range of payment and service products used within each relation.

Unfortunately, the survey does not provide information on the contract terms (i.e. interest rate type, maturity, or leverage) of mortgages. Thus, while we are able to examine how the scope, duration and geographical proximity of bank relationships are related to the incidence of a mortgage, we are unable to examine their impact on mortgage terms. BASTEN and Косн (2013) use data from an online mortgage broker to examine the mortgage terms (maturity, interest rate, fixed vs. flexible rate) demanded by Swiss households and offered to them by banks.

\subsection{Methodology}

Our first empirical question is to what extent households maintain close or loose relationships with their mortgage lenders. Are households with mortgages more likely to have multiple bank relationships? And if so, how does the duration, proximity and scope of mortgage relationships compare to that of other bank relations of the same household? We examine the closeness of mortgage relations in two steps.

As summarized by equation (1) we first conduct a household-level analysis in which we relate the number of bank relations of a household to whether the household has a mortgage or not. For this analysis we use two dependent variables: Multiple banks is a dummy variable which is one for households which have at least two bank relations and zero for households with only one bank relation. Bank relations captures the total number of bank relations a household has. The explanatory variable in this analysis is a dummy variable which is one if the household has a Mortgage and zero otherwise. The relation between having a mortgage and the number of bank relations of a household is likely to be 
confounded by demand and supply factors. We include a vector $X_{b}$ of household characteristics and the use of non-mortgage financial products (Wealth, Income, Education, Financial literacy, Age, Retirement account, Investment account), and $Z_{l}$ local characteristics (Rural, Banks close) to control for differences in the supply of financial services. We estimate equation with a linear model.

$$
\underset{\text { Multiple banks }_{h, l}}{\text { Bank relations }_{h, l}}=\alpha+\beta_{1} \cdot \text { Mortgage }_{h}+\beta_{2} \cdot X_{h}+\beta_{3} \cdot Z_{l}+\varepsilon_{b, l}
$$

Our coefficient of interest from the estimation of equation (1) is $\beta_{1}$ which indicates whether households with a mortgage have more bank relations than comparable households without a mortgage.

Even if mortgage borrowers do maintain more bank relations than households without a mortgage this does not imply that mortgage relations themselves are loose. It may well be that mortgages are held with banks that are very close to the household, that the household has been a client of for many years and which the borrower uses for payment and savings transactions. The second step of our empirical analysis therefore focuses on mortgage borrowers which have multiple bank relations. This allows us to compare the characteristics of mortgage relations versus non-mortgage relations of the same households. Of the 687 households which have a mortgage 470 households report at least two bank relations. Thus, our subsample for this analysis covers $68 \%$ of the mortgage borrowers in the full dataset.

Equation (2) summarizes the second step of our empirical approach. For the relation of household $h$ with bank $b$ we relate the incidence of a Mortgage $e_{h, b}$ to indicators of relation Duration, geographical Proximity, as well as the Scope of payment and savings services the bank relation is used for. Household-level fixed effects $\alpha_{b}$ account for unobserved heterogeneity across households. Bank-level fixed effects $\alpha_{b}$ account for differences in mortgage contract terms and the supply of other financial services across banks. We estimate model (2) using a linear probability model. Robustness tests presented in Table 6 show similar results of a non-linear (logit) model. ${ }^{14}$

14 Ai and Norton (2003) discuss the difficulties of interpreting the marginal effects of interaction terms in non-linear models. As we add interaction terms to model (1) in Table 4 we choose to consistently employ the linear probability model throughout our main analysis. 


$$
\begin{aligned}
\text { Mortgage }_{h, b} & =\alpha_{b}+\alpha_{b}+\beta_{1} \cdot \text { Duration }_{h, b} \\
& +\beta_{2} \cdot \text { Proximity }_{h, b}+\beta_{3} \cdot \text { Scope }_{h, b}+\varepsilon_{h, b}
\end{aligned}
$$

Our coefficients of interest in equation (2) are $\beta_{1}, \beta_{2}$ and $\beta_{3}$ which capture whether the mortgage relations of a given household are longer in tenure, geographically closer and broader in scope than the non-mortgage bank relations of the same household. If convenience and/or information asymmetries shape mortgage relations we expect this to be the case.

Our second research question examines which households are most likely to maintain tight mortgage relationships. Can tight mortgage relationships be explained by asymmetric information about the borrower, as suggested by the theory of financial intermediation? Or alternatively, can tight mortgage relationships be explained by convenience of financial unsophisticated households as suggested by the marketing literature? We explore this question by estimating the variation of coefficients $\beta_{1}, \beta_{2}$ and $\beta_{3}$ in equation (2) across different types of households. Specifically we estimate equation (2) interacting the variables Duration, Proximity and Scope with measures of household financial sophistication (proxied by Income, Wealth, Education, Financial literacy) and opaqueness of financial conditions (proxied by Age and Rural).

If (a lack of) financial sophistication is responsible for the closeness of mortgage relations we would expect households with high income and wealth, as well as high education and financial literacy to maintain less tight mortgage relations. If information asymmetries are responsible for the characteristics of mortgage relations we would expect financially opaque households to have tighter mortgage relations. In line with the literature on relationship banking (see e.g. BERGER and UDELL, 1995) we conjecture that older borrowers are less opaque in terms of their ability and willingness to repay mortgages than younger borrowers, for example because they may already have built up a credit history. Also, information asymmetries about the creditworthiness of households may be less severe in small, rural towns as informal information exchange and social control may be more intense. We thus conjecture that if information asymmetries provide the rationale behind the tightness of mortgage relations we would expect older households and households in rural areas to have less tight mortgage relations than young, urban households. ${ }^{15}$

15 We are unable to use self-employment as a measure of opaqueness as our survey does not cover self-employed households. The reason is that we wanted to make sure we were eliciting information on personal bank relationships as opposed to bank relationships which might be (partly) used for business purposes. 


\section{Results}

\subsection{Number of Bank Relations}

Table 1 presents a univariate comparison of households which have a mortgage to households which do not have a mortgage. The table documents that mortgage borrowers have more bank relations. Among those households with a mortgage $68 \%$ have multiple bank relations compared to only $52 \%$ among the households without a mortgage. On average households with a mortgage have 2.1 bank relations compared to 1.8 relations for households without a mortgage.

Table 1: Mortgage borrowing, household characteristics and bank relations

\begin{tabular}{lccc}
\hline Mortgage & $\begin{array}{c}\text { Yes } \\
(1)\end{array}$ & $\begin{array}{c}\text { No } \\
(2)\end{array}$ & $\begin{array}{c}\text { T-test } \\
(1) \text { vs. }(2)\end{array}$ \\
\hline Multiple banks & 0.68 & 0.52 & $* * *$ \\
\hline Bank relations & 2.10 & 1.79 & $* * *$ \\
Wealth & 2.13 & 1.77 & $* * *$ \\
Income & 3.40 & 2.83 & $* * *$ \\
\hline Education & 3.79 & 3.74 & $* * *$ \\
\hline Financial literacy & 0.57 & 0.44 & $* * *$ \\
Age & 49.4 & 42.8 & $* * *$ \\
Rural & 0.66 & 0.79 & $* * *$ \\
Banks close & 2.87 & 3.21 & $* * *$ \\
Retirement account & 0.54 & 0.30 & $* * *$ \\
Investment acount & 0.43 & 0.30 & $\mathrm{n}=1,481$ \\
\hline Observations & $\mathrm{n}=687$ & $\mathrm{n}=794$ & $*$ \\
\hline
\end{tabular}

Notes: This table reports mean characteristics of households comparing households which have a mortgage and households with no mortgage. The t-tests report statistical significance of twosided t-tests. ${ }^{* * *},{ }^{* *},{ }^{*}$ denote significance at the $0.01,0.05,0.10$-level, respectively. Definitions of all variables are provided in the Appendix.

Table 1, however, also documents that households differ strongly with respect to a wide range of characteristics which may confound the relationship between mortgage borrowing and the number of bank relations. Households with a mortgage have higher income, higher wealth and are older than households without a mortgage. While mortgage borrowers do not display higher levels of general education, they do exhibit higher levels of financial literacy. Households without 
a mortgage are more likely to live in rural areas, and in areas with less bank branches. Finally, we see that households with a mortgage are also more likely to use other sophisticated financial products (i.e. services beyond ordinary payment and savings services): They are more likely to have a retirement account or an investment account than households without a mortgage.

The multivariate analysis in Table 2 controls for confounding household-level and regional-level indicators and suggests that mortgage borrowers do maintain more bank relations than similar households without a mortgage. The point estimates for Mortgage in columns (1)-(3) suggest that households with a mortgage are 11 percentage points more likely to have multiple bank relations rather than a single bank relation. The column (4)-(6) estimates suggest that on average households with a mortgage have 0.2 more bank relations than similar households without a mortgage. Both effects are sizeable in economic terms as compared to the sample averages: $59 \%$ of households in the sample have multiple bank relations and the average number of bank relations is 1.9.

\subsection{Duration, Proximity and Scope of Bank Relations}

The results so far suggest that households with a mortgage do maintain significantly more bank relations than similar households without a mortgage. However, a larger number of bank relations, does not imply that mortgage relations themselves are "loose". In this section we focus on those mortgage borrowers which have multiple bank relations and we compare the duration, proximity and scope of their mortgage relations to their non-mortgage bank relations.

Table 3 presents a univariate comparison of mortgage relations versus non-mortgage bank relations. The table documents significant differences in relation duration, proximity and scope. Banks with which households have a mortgage are located closer to the household $(67 \%$ within $5 \mathrm{~km})$ than banks with which households maintain non-mortgage relations $(51 \%$ within $5 \mathrm{~km})$. While most bank relations in our sample are long-term, mortgage relations are less likely to have a long duration (63\% longer than 10 years) than non-mortgage relations (70\% longer than 10 years). Mortgage relations are characterized by a broader scope of savings and payments transactions than non-mortgage relations: On average, mortgage relations are used as the main account for 2.1 transaction types, while non-mortgage relations are used for 1.3 transaction types. Regular Incoming payments and Outgoing payments are more likely to flow through the mortgage bank $(43 \%)$ than through a non-mortgage relation (31\%, 32\%). Household savings activities - for durables/ investments as well as for retirement - are also more likely to be conducted within a mortgage relation $(46 \%, 37 \%)$ than within a non-mortgage relation $(24 \%, 9 \%)$. 
Table 2: Mortgage borrowing and bank relations

\begin{tabular}{|c|c|c|c|c|c|c|}
\hline \multicolumn{7}{|l|}{ Sample: All households } \\
\hline \multirow[t]{2}{*}{ Dependent variable } & \multicolumn{3}{|c|}{ Multiple banks } & \multicolumn{3}{|c|}{ Bank relations } \\
\hline & (1) & (2) & (3) & (4) & (5) & (6) \\
\hline Mortgage & $\begin{array}{c}0.110^{* * *} \\
{[0.0282]}\end{array}$ & $\begin{array}{c}0.113^{* * *} \\
{[0.0287]}\end{array}$ & $\begin{array}{c}0.119^{* * *} \\
{[0.0294]}\end{array}$ & $\begin{array}{c}0.207^{* * *} \\
{[0.0570]}\end{array}$ & $\begin{array}{l}0.194^{* * *} \\
{[0.0582]}\end{array}$ & $\begin{array}{l}0.208^{* * *} \\
{[0.0599]}\end{array}$ \\
\hline Income & $\begin{array}{c}0.0139 \\
{[0.0112]}\end{array}$ & $\begin{array}{c}0.0143 \\
{[0.0113]}\end{array}$ & $\begin{array}{c}0.0141 \\
{[0.0113]}\end{array}$ & $\begin{array}{c}0.000173 \\
{[0.0226]}\end{array}$ & $\begin{array}{c}-0.00363 \\
{[0.0228]}\end{array}$ & $\begin{array}{c}-0.00415 \\
{[0.0229]}\end{array}$ \\
\hline Wealth & $\begin{array}{l}0.0623^{* * *} \\
{[0.0139]}\end{array}$ & $\begin{array}{l}0.0501^{* * *} \\
{[0.0150]}\end{array}$ & $\begin{array}{c}0.0503^{* * *} \\
{[0.0150]}\end{array}$ & $\begin{array}{c}0.217^{* * *} \\
{[0.0315]}\end{array}$ & $\begin{array}{l}0.182^{* * *} \\
{[0.0345]}\end{array}$ & $\begin{array}{c}0.182^{* * *} \\
{[0.0345]}\end{array}$ \\
\hline Education & $\begin{array}{c}0.0194 \\
{[0.0119]}\end{array}$ & $\begin{array}{c}0.0183 \\
{[0.0119]}\end{array}$ & $\begin{array}{c}0.0159 \\
{[0.0120]}\end{array}$ & $\begin{array}{l}0.0656^{* * *} \\
{[0.0234]}\end{array}$ & $\begin{array}{l}0.0613^{* * *} \\
{[0.0233]}\end{array}$ & $\begin{array}{l}0.0561^{* *} \\
{[0.0233]}\end{array}$ \\
\hline Financial literacy & $\begin{array}{c}0.118^{* * *} \\
{[0.0283]}\end{array}$ & $\begin{array}{c}0.110^{* * *} \\
{[0.0284]}\end{array}$ & $\begin{array}{c}0.109^{* * *} \\
{[0.0284]}\end{array}$ & $\begin{array}{c}0.177^{* * *} \\
{[0.0547]}\end{array}$ & $\begin{array}{c}0.154^{* * *} \\
{[0.0547]}\end{array}$ & $\begin{array}{c}0.152^{* * *} \\
{[0.0545]}\end{array}$ \\
\hline Age & $\begin{array}{c}0.00246^{* *} \\
{[0.00116]}\end{array}$ & $\begin{array}{c}0.00221^{*} \\
{[0.00117]}\end{array}$ & $\begin{array}{c}0.00211^{*} \\
{[0.00117]}\end{array}$ & $\begin{array}{c}0.0022 \\
{[0.00220]}\end{array}$ & $\begin{array}{c}0.0021 \\
{[0.00224]}\end{array}$ & $\begin{array}{c}0.00189 \\
{[0.00226]}\end{array}$ \\
\hline Retirement account & & $\begin{array}{c}-0.0241 \\
{[0.0286]}\end{array}$ & $\begin{array}{c}-0.0219 \\
{[0.0286]}\end{array}$ & & $\begin{array}{c}0.0336 \\
{[0.0596]}\end{array}$ & $\begin{array}{c}0.0384 \\
{[0.0597]}\end{array}$ \\
\hline Investment account & & $\begin{array}{l}0.0815^{* * *} \\
{[0.0309]}\end{array}$ & $\begin{array}{l}0.0818^{* * *} \\
{[0.0309]}\end{array}$ & & $\begin{array}{c}0.188^{* * *} \\
{[0.0667]}\end{array}$ & $\begin{array}{c}0.188^{* * *} \\
{[0.0665]}\end{array}$ \\
\hline Rural & & & $\begin{array}{c}-0.0115 \\
{[0.0316]}\end{array}$ & & & $\begin{array}{c}-0.0236 \\
{[0.0618]}\end{array}$ \\
\hline Banks close & & & $\begin{array}{c}0.0214^{*} \\
{[0.0129]}\end{array}$ & & & $\begin{array}{c}0.0456^{*} \\
{[0.0248]}\end{array}$ \\
\hline Constant & $\begin{array}{c}0.146^{* *} \\
{[0.0700]}\end{array}$ & $\begin{array}{c}0.167^{* *} \\
{[0.0704]}\end{array}$ & $\begin{array}{c}0.121 \\
{[0.0763]}\end{array}$ & $\begin{array}{l}0.996^{* * *} \\
{[0.135]}\end{array}$ & $\begin{array}{l}1.033^{* * *} \\
{[0.136]}\end{array}$ & $\begin{array}{l}0.933^{* * *} \\
{[0.147]}\end{array}$ \\
\hline Mean of dependent & 0.59 & 0.59 & 0.59 & 1.93 & 1.93 & 1.93 \\
\hline Observations & 1286 & 1286 & 1286 & 1286 & 1286 & 1286 \\
\hline Households & 1286 & 1286 & 1286 & 1286 & 1286 & 1286 \\
\hline R-squared & 0.093 & 0.098 & 0.100 & 0.122 & 0.129 & 0.131 \\
\hline Method & OLS & OLS & OLS & OLS & OLS & OLS \\
\hline
\end{tabular}

Notes: The dependent variables in this table are Multiple banks (columns (1)-(3)) and Bank relationships (columns (4)-(6)). Robust standard errors are reported in parentheses. ${ }^{* * *},{ }^{* *},{ }^{*}$ denote significance at the $0.01,0.05$ and 0.10 -level. Definitions of all variables are provided in the Appendix. 
Table 3: Mortgage vs. non-mortgage bank relations

\begin{tabular}{|c|c|c|c|}
\hline \multicolumn{4}{|c|}{ Sample: Households with a mortgage and multiple bank relations } \\
\hline Mortgage relationship: & $\begin{array}{l}\text { Yes } \\
(1)\end{array}$ & $\begin{array}{l}\text { No } \\
(2)\end{array}$ & $\begin{array}{c}\text { T-test } \\
\text { (1) vs. (2) }\end{array}$ \\
\hline Duration $>10$ years & 0.63 & 0.70 & $* * *$ \\
\hline Distance $\leq 5 \mathrm{~km}$ & 0.67 & 0.51 & $* * *$ \\
\hline Transaction scope & 2.07 & 1.31 & $* * *$ \\
\hline Incoming payments & 0.43 & 0.32 & $* * *$ \\
\hline Outgoing payments & 0.43 & 0.31 & $* * *$ \\
\hline ATM withdrawals & 0.38 & 0.34 & \\
\hline Savings & 0.46 & 0.24 & $* * *$ \\
\hline Retirement savings & 0.37 & 0.09 & $* * *$ \\
\hline Observations & 540 & 688 & 1,228 \\
\hline Households & 470 & 470 & 470 \\
\hline
\end{tabular}

Notes: This table reports the mean characteristics of bank relations for the sample of households which have a mortgage and multiple bank relations. The table compares mortgage relations to non-mortgage relations. The t-tests report statistical significance of two-sided t-tests. ${ }^{* *},{ }^{* *},{ }^{*}$ denote significance at the $0.01,0.05,0.10$-level, respectively. Definitions of all variables are provided in the Appendix.

The univariate results in Table 3 may be biased due to the fact that (i) the number of bank relations and types of services and products used varies across households and (ii) different banks offer different contract terms for mortgage and non-mortgage products. The multivariate estimates reported in Table 4 account for unobserved heterogeneity across households and banks by including corresponding fixed effects. They confirm the univariate correlations. The column (1) estimates suggest that a relation with a bank which is located within $5 \mathrm{~km}$ of a household is 23 percentage points more likely to feature a mortgage than a bank which is more distant. A bank relation which is older than ten years is 19 percentage points less likely to feature a mortgage than a relation which is less than ten years old. A bank relation which is used for one additional payment or savings service is 5 percentage points more likely to feature a mortgage. The 
economic relevance of relation duration, proximity and scope for the choice of the mortgage bank is substantial given that $44 \%$ of the bank relations in this sample feature a mortgage.

Looking more closely at the scope of bank relations, the column (2)-(7) estimates suggest that there is a particularly strong association between mortgage borrowing and retirement saving. The column (2)-(3) estimates show that bank relations which are used for regular incoming (outgoing) payments are 10 (12) percentage points more likely to feature a mortgage. The column (5) estimates show that bank relations which are used for regular savings are 23 percentage points more likely to feature a mortgage. By comparison, relations which are used for retirement savings are 48 percentage points more likely to also feature a mortgage (column (6)). This effect remains strong if we control for other savings and payment services (column (7)). As mentioned in section 2 the strong association between mortgage borrowing and retirement saving is fostered by institutional features of the Swiss mortgage market. First, retirement savings can be pledged as a down payment on the mortgage. Second, due to the favorable tax treatment of mortgage debt, households may amortize their mortgage indirectly, i.e. through a retirement savings account. It is very likely that retirement savings used a down payment or for indirect amortization are held with the mortgage lender.

A striking result in Table 4 is the strong and robust negative association between the duration of a bank relation and the incidence of a mortgage. This finding is particularly surprising in light of the broad evidence that relation duration improves credit availability for corporate borrowers (KYSUCKI and NORDEN, 2014). In our robustness tests in section 6 we provide evidence that the negative association between the duration of a bank relation and the presence of a mortgage is not driven by old "dormant" accounts of households. The most likely explanation for the negative association between relation duration and mortgage incidence is therefore that households open up new joint accounts when they move together. Our results would suggest that the mortgage is held with the bank where the household has its joint account as opposed to where individual members of the household may have their (pre-existing) individual accounts. This would explain why duration (and distance) is shorter for mortgage relations.

\subsection{Financial Sophistication and Information Asymmetries}

Why do households hold their mortgages with banks that are geographically close and which they use widely for non-credit transactions? The bundling of mortgage loans with payment and saving transactions may be a result of contractual obligations of borrowers. For monitoring purposes mortgage lenders may request 
Table 4: Duration, proximity and scope of bank relations

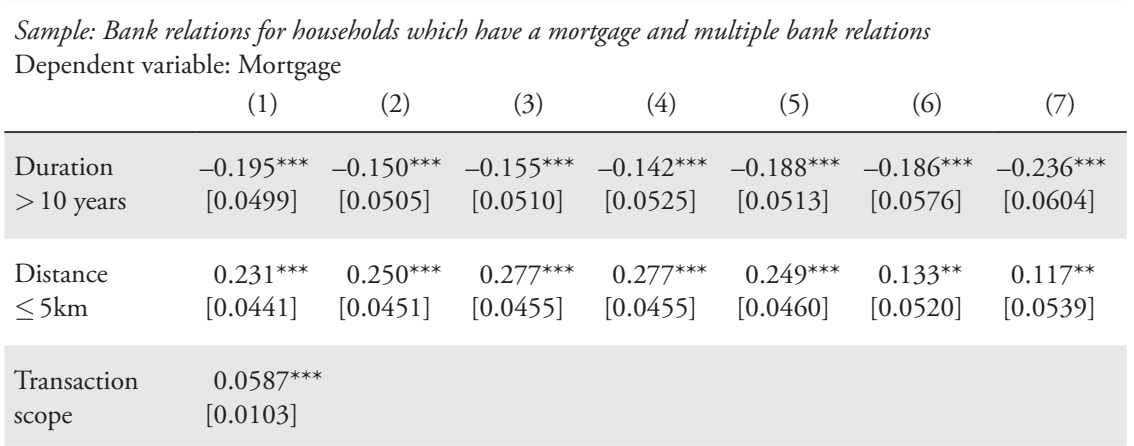

$\begin{array}{lc}\text { Incoming } & 0.0992^{* * *} \\ \text { payments } & {[0.0367]}\end{array}$

$\begin{array}{lcc}\text { Outgoing } & 0.115^{* * *} & 0.0212 \\ \text { payments } & {[0.0368]} & {[0.0471]}\end{array}$

ATM

0.0239

withdrawals

[0.0378]

\begin{tabular}{|c|c|c|c|c|c|c|c|}
\hline Savings & & & & & $\begin{array}{c}0.229^{* * *} \\
{[0.0367]}\end{array}$ & & $\begin{array}{c}0.165^{* * *} \\
{[0.0495]}\end{array}$ \\
\hline $\begin{array}{l}\text { Retirement } \\
\text { savings }\end{array}$ & & & & & & $\begin{array}{c}0.477^{* * *} \\
{[0.0423]}\end{array}$ & $\begin{array}{c}0.422^{* * *} \\
{[0.0472]}\end{array}$ \\
\hline $\begin{array}{l}\text { Household } \\
\text { fixed effects }\end{array}$ & Yes & Yes & Yes & Yes & Yes & Yes & Yes \\
\hline $\begin{array}{l}\text { Bank fixed } \\
\text { effects }\end{array}$ & Yes & Yes & Yes & Yes & Yes & Yes & Yes \\
\hline Observations & 1226 & 1191 & 1168 & 1151 & 1099 & 677 & 624 \\
\hline R-squared & 0.087 & 0.057 & 0.068 & 0.058 & 0.111 & 0.268 & 0.311 \\
\hline Households & 470 & 455 & 446 & 441 & 419 & 262 & 239 \\
\hline Method & OLS & OLS & OLS & OLS & OLS & OLS & OLS \\
\hline
\end{tabular}

Notes: The dependent variable in this table is Mortgage. The sample in column (1) includes all bank relationships of households with a mortgage and at least 2 bank relationships. The samples in columns (2)-(7) include bank relationships only of those households which use at least one of their bank accounts for the respective transaction types. Robust standard errors are reported in parentheses. ${ }^{* * *},{ }^{* *},{ }^{*}$ denote significance at the $0.01,0.05$ and 0.10 -level. Definitions of all variables are provided in the Appendix. 
mortgage borrowers to maintain their wage account with the bank. Moreover, as discussed above households may pledge additional financial assets (retirement accounts, investment accounts) as collateral on a mortgage or may amortize the mortgage indirectly through a retirement savings account. However, contractual obligations do not explain why a household would hold the mortgage with a bank that is geographically close, compared to other active bank relations.

The marketing literature (Blankson et al,. 2007, Devlin, 2002b) suggests that convenience may be responsible for the bundling of mortgages into relationships with easily accessible banks, especially for financially less sophisticated households. Alternatively, the financial intermediation literature (e.g. Воот, 2000) suggests that information asymmetries regarding the creditworthiness of households may be the reason for mortgage relationships with geographically close banks. In Table 5 we examine our second research question: Does financial sophistication and/or asymmetric information, explain the geographical proximity and the broad scope of mortgage relations observed above. Our empirical strategy is to compare the characteristics of mortgage relations across households which vary by income, wealth, education, financial literacy, age and location (see section 3.2).

Table 5 provides some support for the conjecture that the geographical proximity of mortgage relations is related to the financial sophistication of borrowers. In columns (1)-(4) of the table we present estimates of equation (2) including interaction terms of relation duration, proximity and scope with indicators for household income, wealth, education, and financial literacy. ${ }^{16}$ The estimates reported for the interaction terms High wealth $*$ Distance $\leq 5 \mathrm{~km}$, High education $*$ Distance $\leq 5 \mathrm{~km}$ and Financial literacy $*$ Distance $\leq 5 \mathrm{~km}$ in columns (2) -(4) are all significant and negative, suggesting that the proximity of a bank is less important for mortgage choice among households with high wealth, high education and high financial literacy. This result supports the finding of Devlin (2002b) that financially sophisticated households are less likely to choose banking solutions based on convenience.

The results presented in columns (5)-(6) of Table 5 suggest that information asymmetries between banks and households may not be the key determinants of mortgage relations. The estimated interaction terms Age $\geq 50 * D i s-$ tance $\leq 5 \mathrm{~km}$ and Rural $*$ Distance $\leq 5 \mathrm{~km}$ as well as Agee $\geq 50 *$ Transaction scope, and Rural* Transaction scope are all statistically insignificant. This suggests that,

16 Note the main effects of the household level variables are subsumed in the household fixed effects. 
Table 5: Financial sophistication and asymmetric information

\begin{tabular}{|c|c|c|c|c|c|c|}
\hline \multicolumn{7}{|c|}{ Dependent variable: Mortgage } \\
\hline & (1) & (2) & (3) & (4) & (5) & (6) \\
\hline $\begin{array}{l}\text { Duration } \\
>10 \text { years }\end{array}$ & $\begin{array}{l}-0.206^{* * *} \\
{[0.0738]}\end{array}$ & $\begin{array}{c}-0.273^{* * *} \\
{[0.0705]}\end{array}$ & $\begin{array}{l}-0.253^{* * *} \\
{[0.0646]}\end{array}$ & $\begin{array}{c}-0.162^{* *} \\
{[0.0809]}\end{array}$ & $\begin{array}{l}-0.408^{* * *} \\
{[0.0650]}\end{array}$ & $\begin{array}{c}-0.308^{* * *} \\
{[0.0936]}\end{array}$ \\
\hline $\begin{array}{l}\text { Distance } \\
\leq 5 \mathrm{~km}\end{array}$ & $\begin{array}{c}0.283^{* * *} \\
{[0.0619]}\end{array}$ & $\begin{array}{c}0.281^{* * *} \\
{[0.0598]}\end{array}$ & $\begin{array}{c}0.301^{* * *} \\
{[0.0546]}\end{array}$ & $\begin{array}{c}0.374^{* * *} \\
{[0.0695]}\end{array}$ & $\begin{array}{c}0.204^{* * *} \\
{[0.0585]}\end{array}$ & $\begin{array}{c}0.280^{* * *} \\
{[0.0747]}\end{array}$ \\
\hline Transaction scope & $\begin{array}{c}0.0666^{* * *} \\
{[0.0147]}\end{array}$ & $\begin{array}{l}0.0610^{* * *} \\
{[0.0144]}\end{array}$ & $\begin{array}{l}0.0676^{* * *} \\
{[0.0128]}\end{array}$ & $\begin{array}{c}0.0344^{* *} \\
{[0.0165]}\end{array}$ & $\begin{array}{l}0.0603^{* * *} \\
{[0.0141]}\end{array}$ & $\begin{array}{c}0.0529^{* * *} \\
{[0.0182]}\end{array}$ \\
\hline Interaction terms: & $\begin{array}{c}\text { High } \\
\text { income* }\end{array}$ & $\begin{array}{c}\text { High } \\
\text { wealth* }\end{array}$ & $\begin{array}{c}\text { High } \\
\text { education* }\end{array}$ & $\begin{array}{l}\text { Financial } \\
\text { literacy* }^{*}\end{array}$ & $\begin{array}{l}\text { High } \\
\text { age }\end{array}$ & Rural $^{*}$ \\
\hline $\begin{array}{l}\text { Duration } \\
>10 \text { years }\end{array}$ & $\begin{array}{c}0.0282 \\
{[0.105]}\end{array}$ & $\begin{array}{c}0.183^{*} \\
{[0.108]}\end{array}$ & $\begin{array}{c}0.137 \\
{[0.101]}\end{array}$ & $\begin{array}{c}-0.0457 \\
{[0.103]}\end{array}$ & $\begin{array}{c}0.494^{* * *} \\
{[0.0994]}\end{array}$ & $\begin{array}{c}0.155 \\
{[0.111]}\end{array}$ \\
\hline $\begin{array}{l}\text { Distance } \\
\leq 5 \mathrm{~km}\end{array}$ & $\begin{array}{l}-0.117 \\
{[0.0938]}\end{array}$ & $\begin{array}{c}-0.196^{* *} \\
{[0.0975]}\end{array}$ & $\begin{array}{c}-0.197^{* *} \\
{[0.0921]}\end{array}$ & $\begin{array}{c}-0.240^{* * *} \\
{[0.0897]}\end{array}$ & $\begin{array}{c}0.0518 \\
{[0.0874]}\end{array}$ & $\begin{array}{c}-0.0732 \\
{[0.0926]}\end{array}$ \\
\hline Transaction scope & $\begin{array}{c}-0.0081 \\
{[0.0216]}\end{array}$ & $\begin{array}{c}-0.00554 \\
{[0.0223]}\end{array}$ & $\begin{array}{c}-0.0237 \\
{[0.0213]}\end{array}$ & $\begin{array}{c}0.0404^{*} \\
{[0.0210]}\end{array}$ & $\begin{array}{c}-0.00818 \\
{[0.0202]}\end{array}$ & $\begin{array}{c}0.00774 \\
{[0.0220]}\end{array}$ \\
\hline $\begin{array}{l}\text { Household fixed } \\
\text { effects }\end{array}$ & Yes & Yes & Yes & Yes & Yes & Yes \\
\hline Bank fixed effects & Yes & Yes & Yes & Yes & Yes & Yes \\
\hline Observations & 1108 & 1086 & 1226 & 1226 & 1226 & 1226 \\
\hline Households & 426 & 416 & 470 & 470 & 470 & 470 \\
\hline R-squared & 0.096 & 0.093 & 0.096 & 0.099 & 0.119 & 0.091 \\
\hline Method & OLS & OLS & OLS & OLS & OLS & OLS \\
\hline
\end{tabular}

Notes: The dependent variable in this table is Mortgage. High income households are households with at least 9,000 CHF income per month income. High wealth households are households with at least 100,000 CHF in financial wealth. High education respondents are respondents with tertiary education. Respondents with Financial literacy are those which respond correctly to three financial literacy questions on compound interest, inflation and diversification. High age respondents are respondents between 51 and 74 years of age. Rural households are households located in a town or village of less than 5,000 inhabitants. Robust standard errors are reported in parentheses. ${ }^{* * *},{ }^{* *},{ }^{*}$ denote significance at the $0.01,0.05$ and 0.10 -level. Definitions of all variables are provided in the Appendix. 
when it comes to mortgage bank choice, bank proximity and relation scope are equally important for old and young households as well as for rural and urban households. This finding does not rule out that banks may be more reluctant to lend to young and urban households with which they do not have tight relations. However, our results do suggest that the impact of information asymmetries on mortgage supply to such households may be offset by the higher propensity of young and urban households to shop around for their financial service providers (KISER, 2002).

\subsection{Robustness Tests}

Table 6 reports robustness checks of our multivariate analyses. Panel A presents robustness checks of our Table 2 estimates for equation (1). Panel B presents robustness checks of our Table 4 estimates for equation (2).

In Tables 2 and 4 all multivariate specifications are based on linear estimates although two of our dependent variables are dummy variables; Multiple banks in Table 2 and Mortgage in Table 4. In Panel A of Table 6, column (1), we present non-linear estimates for equation (1) with Multiple banks as the dependent variable. In Panel B of Table 6, column (1), we present non-linear estimates of equation (2) with Mortgage as the dependent variable. In both cases we confirm the estimates of the linear probability model.

Next we examine whether our results may be driven by the financing of privately owned buy-to-let premises as opposed to owner-occupied housing. Unfortunately, our data does not distinguish mortgages used for owner-occupied housing from mortgages on buy-to-let premises. Given the low rate of owner-occupied housing in Switzerland it is thus possible that our results are at least partly driven by the financing of landlords. Assuming that landlords dispose not only over higher real wealth but also higher financial wealth, we exclude 134 households (10\% of our sample) with financial wealth exceeding 250,000 CHF. The results presented in Panel A, columns (2) and (4), and Panel B, column (2), of Table 6 do not differ economically or statistically from our estimates in Tables 2 and 4.

In further robustness tests we examine to what extent our results may be driven by "dormant" accounts of households. If a substantial share of bank relations in our sample are dormant this may explain why non-mortgage relations of mortgage holders are characterized by a narrower scope than their mortgage relations. Moreover, if dormant non-mortgage relations were established when the household was young and living in a different region this would explain why on average non-mortgage relations of mortgage holders are characterized by a longer duration and greater geographical distance between the household and the bank. 
In Panel A of Table 6, columns (3) and (5), we replicate columns (1) and (3) of Table 2, limiting our analysis to active bank relations only. We hereby define an active bank relation as one which is used as the main bank-relation for at least one type of payment or savings transaction. In Panel B of Table 6, column (3), we replicate column (1) of Table 4 limiting our sample to mortgage holders with at least two active bank relations. In this specification we reduce our sample size by more than half to 468 bank relations of 225 mortgage holders. The reported estimates in these robustness tests suggest that our main results are not driven by dormant accounts.

Finally, in Panel B, column (4), of Table 6 we replicate our analysis measuring the scope of bank relations by the range of products used, rather than the range of transactions conducted. The results confirm the broader scope of mortgage relations compared to non-mortgage relations: Mortgages are more likely to be held at banks where households have a current account, a savings account, a retirement savings account or a custody account for securities transactions.

We also conduct robustness tests for our analysis of the role of financial sophistication and asymmetric information. We replicate the Table 5 results using the variable Retirement savings rather than Transaction scope as our indicator of the scope of the bank relation. This robustness check is motivated by the finding in Table 4 that the association between mortgage borrowing and retirement savings is particularly strong. The (unreported) results confirm our Table 5 findings: The impact of the scope of a bank relation on the presence of a mortgage does not vary significantly across household types. This finding provides further support to the conjecture that the coincidence of mortgage borrowing and retirement saving within a bank relation may be explained by contractual obligations as opposed to information asymmetries or convenience. 
Table 6. Robustness tests

Panel A. Mortgage borrowing and bank relations

\begin{tabular}{|c|c|c|c|c|c|}
\hline \multicolumn{6}{|l|}{ Sample: All households } \\
\hline \multirow[t]{2}{*}{ Dependent variable } & \multicolumn{3}{|c|}{ Multiple banks } & \multicolumn{2}{|c|}{ Bank relations } \\
\hline & (1) & (2) & (3) & (4) & (5) \\
\hline Mortgage & $\begin{array}{c}0.109^{* * *} \\
{[0.0272]}\end{array}$ & $\begin{array}{c}0.135^{* * *} \\
{[0.0304]}\end{array}$ & $\begin{array}{l}0.0807^{* * *} \\
{[0.0280]}\end{array}$ & $\begin{array}{c}0.261^{* * *} \\
{[0.0585]}\end{array}$ & $\begin{array}{l}0.0800^{* *} \\
{[0.0315]}\end{array}$ \\
\hline Income & $\begin{array}{l}0.014 \\
{[0.0114]}\end{array}$ & $\begin{array}{c}0.0168 \\
{[0.0121]}\end{array}$ & $\begin{array}{r}0.00301 \\
{[0.0110]}\end{array}$ & $\begin{array}{c}0.0209 \\
{[0.0227]}\end{array}$ & $\begin{array}{c}0.0121 \\
{[0.0128]}\end{array}$ \\
\hline Wealth & $\begin{array}{c}0.0669^{* * *} \\
{[0.0146]}\end{array}$ & $\begin{array}{l}0.0586^{* * *} \\
{[0.0192]}\end{array}$ & $\begin{array}{l}0.0427^{* * *} \\
{[0.0149]}\end{array}$ & $\begin{array}{c}0.179^{* * *} \\
{[0.0386]}\end{array}$ & $\begin{array}{c}0.0394^{* *} \\
{[0.0172]}\end{array}$ \\
\hline Education & $\begin{array}{c}0.0196 \\
{[0.0120]}\end{array}$ & $\begin{array}{c}0.0250^{*} \\
{[0.0129]}\end{array}$ & $\begin{array}{c}0.0123 \\
{[0.0114]}\end{array}$ & $\begin{array}{l}0.0731^{* * *} \\
{[0.0244]}\end{array}$ & $\begin{array}{c}0.0172 \\
{[0.0129]}\end{array}$ \\
\hline Financial literacy & $\begin{array}{c}0.113^{* * *} \\
{[0.0266]}\end{array}$ & $\begin{array}{c}0.120^{* * *} \\
{[0.0300]}\end{array}$ & $\begin{array}{l}0.04 \\
{[0.0272]}\end{array}$ & $\begin{array}{c}0.157^{* * *} \\
{[0.0557]}\end{array}$ & $\begin{array}{c}0.0255 \\
{[0.0312]}\end{array}$ \\
\hline Age & $\begin{array}{c}0.00237^{* *} \\
{[0.00112]}\end{array}$ & $\begin{array}{c}0.00212^{*} \\
{[0.00123]}\end{array}$ & $\begin{array}{c}-0.00169 \\
{[0.00108]}\end{array}$ & $\begin{array}{c}0.0013 \\
{[0.00223]}\end{array}$ & $\begin{array}{c}-0.00192 \\
{[0.00121]}\end{array}$ \\
\hline Constant & & $\begin{array}{c}0.167^{* *} \\
{[0.0704]}\end{array}$ & $\begin{array}{c}0.121 \\
{[0.0763]}\end{array}$ & $\begin{array}{l}0.996^{* * *} \\
{[0.135]}\end{array}$ & $\begin{array}{l}1.033^{* * *} \\
{[0.136]}\end{array}$ \\
\hline Mean of dependent & 0.59 & 0.57 & 0.29 & 1.86 & 1.31 \\
\hline Observations & 1286 & 1152 & 1278 & 1152 & 1278 \\
\hline Households & 1286 & 1286 & 1286 & 1286 & 1286 \\
\hline R-squared & & 0.080 & 0.027 & 0.090 & 0.023 \\
\hline Method & Logit & OLS & OLS & OLS & OLS \\
\hline
\end{tabular}

Notes: The dependent variables in this Panel are Multiple banks (columns (1)-(3)) and Bank relations (columns (4)-(5)). Column (1) replicates column (1) of Table 2 with a non-linear estimation model, presenting marginal effects of logit estimates. Columns (2) and (4) replicate columns (1) and (4) of Table 2 excluding all households with reported financial wealth exceeding 250,000 CHF. Columns (3) and (5) replicate columns (1) and (4) of Table 2 excluding all non-active bank relations. We define an active bank relation as a relation which is used as the main account for at least one transaction type. Robust standard errors are reported in parentheses. ${ }^{* *},{ }^{* *},{ }^{*}$ denote significance at the 0.01, 0.05 and 0.10-level. Definitions of the variables are provided in the Appendix. 


\section{Table 6 continued}

Panel B. Duration, proximity and scope of bank relations

Sample: Bank relation of households which have a mortgage and multiple bank relations

Dependent variable: Mortgage

(2)

(3)

(4)

\begin{tabular}{lcccc}
\hline Duration $>10$ years & $\begin{array}{c}-0.612^{* * *} \\
{[0.157]}\end{array}$ & $\begin{array}{c}-0.252^{* * *} \\
{[0.0596]}\end{array}$ & $\begin{array}{c}-0.298^{* * *} \\
{[0.0913]}\end{array}$ & $\begin{array}{c}-0.227^{* * *} \\
{[0.0488]}\end{array}$ \\
\hline Distance $\leq 5 \mathrm{~km}$ & $\begin{array}{ccc} \\
0.724^{* * *}\end{array}$ & $\begin{array}{c}0.210^{* * *} \\
{[0.143]}\end{array}$ & $0.384^{* * *}$ & $0.190^{* * *}$ \\
& & & {$[0.0768]$} & {$[0.0437]$} \\
Transaction scope & $0.172^{* * *}$ & $0.0581^{* * *}$ & 0.0102 & \\
& {$[0.0320]$} & {$[0.0123]$} & {$[0.0260]$} &
\end{tabular}

Product scope

$0.171^{* * *}$

[0.0209]

\begin{tabular}{lcccc}
\hline Mean of dependent & 0.44 & 0.44 & 0.47 & 0.44 \\
Household Fixed Effects & Yes & Yes & Yes & Yes \\
Bank Fixed Effects & Yes & Yes & Yes & Yes \\
Observations & 1150 & 891 & 468 & 1226 \\
R-squared & 436 & 0.087 & 0.126 & 0.125 \\
Households & Logit & OLS & OLS & OLS \\
\hline Method & & 349 & 225 & 470 \\
\hline
\end{tabular}

Notes: The dependent variable in this Panel is Mortgage. Column (1) replicates column (1) of Table 3 with a non-linear (logit) model. Column (2) exlcudes all households with reported financial wealth exceeding 250,000 CHF. Column (3) replicates column (1) of Table 3 considering only those households with a mortgage and multiple active bank relations. We define an active bank relation as a relation which is used as the main account for at least one transaction type. Column (4) replicates column (1) of Table 4 using the products used as opposed to the transactions used per bank relation as a measure of relationship scope. Robust standard errors are reported in parentheses. ${ }^{* * *},{ }^{* *},{ }^{*}$ denote significance at the $0.01,0.05$ and 0.10 -level. Definitions of all variables are provided in the Appendix. 


\section{Conclusion}

Based on survey data covering all bank relations of 1,481 Swiss households we examine to what extent the residential mortgage market is characterized by relationship banking. We document that mortgage borrowers have more bank relations than comparable households without a mortgage. However, this does not imply that mortgage relations themselves are loose. Comparing mortgage relations to other bank relations of the same households we find that mortgage relations are used for a broader scope of transactions and are held with banks that are located closer to the household. However, mortgage relations have on average been more recently established than non-mortgage relations of the same household. Examining the heterogeneity of mortgage relations across households, we find that financially sophisticated households are less likely to hold their mortgage with a local bank.

Our results suggest that mortgages are typically held at the current "housebank" of the household, but that this house-bank is not necessarily the bank with which a household has its longest active relation. This finding is consistent with evidence from the marketing literature suggesting that households choose the provider of financial services based on existing relations and convenience. Note, however, that our findings are also consistent with households choosing their mortgage relation independent of existing relations and subsequently switching non-credit products to the mortgage lender. Further research is required to determine to what extent and for which households mortgages are initial or subsequent products.

In line with evidence from the marketing literature we find that the geographical proximity of a bank is less important for the choice of the mortgage bank among wealthier, well-educated and financial literate households. This finding - if confirmed in U.S. data - may contribute to explaining why the incidence of strategic mortgage default during the recent financial crisis seems to have been higher among wealthier households (Morgan STANLEY, 2013; GHENT and KHudLAYK, 2011). Wealthier households are less connected to (or reliant on) their mortgage lenders and thus more prone to default strategically.

Finally, our results suggest that further research is required to understand the impact of information asymmetries on relations, contract types, and lending conditions in the mortgage market. Our findings suggest that information asymmetries may be less important in shaping mortgage relations than business lending relations. 


\section{Appendix: Variable Definitions}

\begin{tabular}{|c|c|c|c|c|c|}
\hline Variable name & Definition & Obs. & Mean & Min & Max \\
\hline \multicolumn{6}{|c|}{ Bank relation characteristics ( $n=2,863$ bank relations) } \\
\hline Mortgage & $\begin{array}{l}\text { Dummy }=1 \text { if bank relation features a } \\
\text { mortgage. }\end{array}$ & 2,863 & 0.26 & 0 & 1 \\
\hline $\begin{array}{l}\text { Duration } \\
>10 \text { years }\end{array}$ & $\begin{array}{l}\text { Dummy }=1 \text { if bank relation is older than } \\
10 \text { years. }\end{array}$ & 2,863 & 0.66 & 0 & 1 \\
\hline $\begin{array}{l}\text { Distance } \\
\leq 5 \mathrm{~km}\end{array}$ & $\begin{array}{l}\text { Dummy }=1 \text { if nearest branch of the bank is } \\
\text { within } 5 \mathrm{~km} \text { of the household location. }\end{array}$ & 2,861 & 0.65 & 0 & 1 \\
\hline $\begin{array}{l}\text { Transaction } \\
\text { scope }\end{array}$ & $\begin{array}{l}\text { Total number of non-credit transaction types } \\
(1-5) \text { for which the bank relation is the main } \\
\text { relation used. }\end{array}$ & 2,863 & 2.19 & 0 & 5 \\
\hline $\begin{array}{l}\text { Incoming } \\
\text { payments }\end{array}$ & $\begin{array}{l}\text { Dummy }=1 \text { if relation is the one mostly used } \\
\text { for receiving wages other regular income. }\end{array}$ & 2,863 & 0.50 & 0 & 1 \\
\hline $\begin{array}{l}\text { Outgoing } \\
\text { payments }\end{array}$ & $\begin{array}{l}\text { Dummy }=1 \text { if relation is the one mostly used } \\
\text { for regular payments. }\end{array}$ & 2,863 & 0.48 & 0 & 1 \\
\hline $\begin{array}{l}\text { ATM } \\
\text { withdrawals }\end{array}$ & $\begin{array}{l}\text { Dummy }=1 \text { if relation is the one mostly used } \\
\text { for ATM withdrawals. }\end{array}$ & 2,863 & 0.49 & 0 & 1 \\
\hline Savings & $\begin{array}{l}\text { Dummy }=1 \text { if relation is the one mostly used } \\
\text { for savings. }\end{array}$ & 2,863 & 0.44 & 0 & 1 \\
\hline $\begin{array}{l}\text { Retirement } \\
\text { savings }\end{array}$ & $\begin{array}{l}\text { Dummy }=1 \text { if relation is the one mostly used } \\
\text { for retirement savings. }\end{array}$ & 2,863 & 0.28 & 0 & 1 \\
\hline Product scope & $\begin{array}{l}\text { Total number of non-mortgage products }(1-4) \\
\text { with the bank. }\end{array}$ & 2,863 & 1.84 & 0 & 4 \\
\hline $\begin{array}{l}\text { Current } \\
\text { account }\end{array}$ & $\begin{array}{l}\text { Dummy }=1 \text { if household has a current account } \\
\text { with the bank. }\end{array}$ & 2,863 & 0.68 & 0 & 1 \\
\hline $\begin{array}{l}\text { Savings } \\
\text { account }\end{array}$ & $\begin{array}{l}\text { Dummy }=1 \text { if household has a savings account } \\
\text { with the bank. }\end{array}$ & 2,863 & 0.64 & 0 & 1 \\
\hline $\begin{array}{l}\text { Retirment } \\
\text { account }\end{array}$ & $\begin{array}{l}\text { Dummy }=1 \text { if household has a tax-exempted } \\
\text { retirement savings account with the bank. }\end{array}$ & 2,863 & 0.26 & 0 & 1 \\
\hline $\begin{array}{l}\text { Custody } \\
\text { account }\end{array}$ & $\begin{array}{l}\text { Dummy }=1 \text { if household has a custody account } \\
\text { for securities transactions with the bank. }\end{array}$ & 2,863 & 0.26 & 0 & 1 \\
\hline
\end{tabular}




\begin{tabular}{|c|c|c|c|c|c|}
\hline Variable name & Definition & Obs. & Mean & Min & Max \\
\hline \multicolumn{6}{|c|}{ Household characteristics ( $n=1,481$ households) } \\
\hline Multiple banks & $\begin{array}{l}\text { Dummy }=1 \text { if household has at least } 2 \text { bank } \\
\text { relations }\end{array}$ & 1,481 & 0.59 & 0 & 1 \\
\hline Bank relations & Number of bank relations of the household & 1,481 & 1.93 & 1 & 6 \\
\hline $\begin{array}{l}\text { Retirement } \\
\text { account }\end{array}$ & $\begin{array}{l}\text { Dummy }=1 \text { if household has a tax-exempted } \\
\text { retirement savings account with any bank. }\end{array}$ & 1,481 & 0.41 & 0 & 1 \\
\hline $\begin{array}{l}\text { Custody } \\
\text { account }\end{array}$ & $\begin{array}{l}\text { Dummy }=1 \text { if household has a custody account } \\
\text { for securities transactions with any bank. }\end{array}$ & 1,481 & 0.36 & 0 & 1 \\
\hline Income & $\begin{array}{l}\text { Household monthly income on a scale of } 1 \\
\text { (below CHF } 4,500 \text { per month) to } 6 \text { ( at least } \\
15,000 \mathrm{CHF} \text { ) }\end{array}$ & 1,346 & 3.09 & 1 & 6 \\
\hline Wealth & $\begin{array}{l}\text { Household wealth on a scale of } 1 \text { ( less than } \\
50,000 \mathrm{CHF} \text { ) to } 5 \text { (at least } 1 \text { million CHF) }\end{array}$ & 1,318 & 1.94 & 1 & 5 \\
\hline Education & $\begin{array}{l}\text { Highest attained education of the respondent } \\
\text { on a scale of } 1 \text { (primary school) to } 6 \text { (university } \\
\text { degree) }\end{array}$ & 1,481 & 3.76 & 1 & 6 \\
\hline $\begin{array}{l}\text { Financial } \\
\text { literacy }\end{array}$ & $\begin{array}{l}\text { Dummy }=1 \text { if household responds to three } \\
\text { financial literacy questions correctly. }\end{array}$ & 1,481 & 0.50 & 0 & 1 \\
\hline Age & Age of respondent in years & 1,481 & 45.87 & 20 & 74 \\
\hline Rural & $\begin{array}{l}\text { Household is located in a town / village with } \\
\text { less than 5,000 inhabitants. }\end{array}$ & 1,481 & 0.73 & 0 & 1 \\
\hline Banks close & $\begin{array}{l}\text { Number of banks with a branch within } 5 \mathrm{~km} \text { of } \\
\text { the town where household located }\end{array}$ & 1,481 & 3.05 & 0 & 4 \\
\hline Rural & $\begin{array}{l}\text { Household is located in a town / village with } \\
\text { less than 5,000 inhabitants. }\end{array}$ & 1,481 & 0.73 & 0 & 1 \\
\hline
\end{tabular}

\section{References}

Agarwal, S., S. Chomsisengphet, C. Liu, and N. S. Souleles (2010), "Benefits of Relationship Banking: Evidence from Consumer Credit Markets", Working Paper Series WP-2010-05, Federal Reserve Bank of Chicago.

Ai, C., and E. C. Norton (2003), "Interaction Terms in Logit and Probit Models”, Economics Letters, 80(1), pp. 123-129. 
Basten, C., and C. Косн (2015), "House Prices, Mortgage Demand and Mortgage Supply: Causal Evidence from a Shift-Share Experiment”, Journal of Housing Economics, 30, pp. 1-22.

Basten, C., B. Guin, and C. Косн (2015), "Demand and Supply of Mortgages: The Role of Interest Rate Risk and Credit Risk", unpublished manuscript.

Beck, T., B. Büyükкarabacak, F. Rioja, and N. Valev (2012), "Who Gets the Credit? And Does It Matter? Household vs Firm Lending Across Countries", B. E. Journal of Macroeconomics, 12(1).

Berger, A., and G. Udell (1995), "Relationship Lending and Lines of Credit in Small Firm Finance”, Journal of Business, 68, pp. 351-381.

Blankson, C., J. Ming-Sung Cheng, and N. Spears (2007), "Determinants of Banks Selection in USA, Taiwan and Ghana", International Journal of Bank Marketing, 25(7), pp.469-489.

Воот, A. W.A. (2000), “Relationship Banking: What Do We Know?”, Journal of Financial Intermediation, 9(1), pp. 7-25.

Brown, M., and R. Graf (2013), "Financial Literacy and Retirment Planning in Switzerland", Numeracy, 6, Article 6.

Brown, M., and B. Guin (2015), "The Exposure of Mortgage Borrowers to Interest Rate Risk and House Price Risk - Evidence from Swiss Loan Application Data”, Swiss Journal of Economics and Statistics, 151(2), pp. 89-123.

Bucks B. K., A. B. Kennickell, T.L. Mach and K. B. Moore (2009), "Changes in U.S. Family Finances from 2004 to 2007: Evidence from the Survey of Consumer Finances", Federal Reserve Bulletin (February), pp. A1-A56.

Devlin, J.F. (2002a), "An Analysis of Choice Criteria in the Home Loans Market", The International Journal of Bank Marketing, 20(4/5), pp. 212-226.

Devlin, J. F. (2002b), "Customer Knowledge and Choice Criteria in Retail Banking”, Journal of Strategic Marketing, 10(4), pp. 273-290.

European Central Bank (2013), "The Euro System Household Finance and Consumption Survey: Results from the First Wave”, Eurosystem Household Finance and Consumption Network Statistics Paper Series No. 2.

Guiso, L., P. Sapienza, and L. Zingales (2013), The Determinants of Attitudes towards Strategic Default on Mortgages, Journal of Finance, 68, pp. 1473-1515.

Ghent, A., and M. Kudlayk (2011), "Recourse and Residential Mortgage Default: Evidence from the U.S. States", Review of Financial Studies 24, pp. 3139-3186.

Holmes, J., J. Isham, R. Petersen, and P. M. Sommers (2007), “Does Relationship Lending Still Matter in the Consumer Banking Sector? Evidence from the Automobile Loan Market", Social Science Quarterly 88(2), pp. 585-597. 
Kiser, E. K. (2002), "Predicting Household Switching Behavior and Switching Costs at Depository Institutions", Review of Industrial Organization, 20(4), pp.349-365.

Kysucky, V., and L. Norden (2016), "The Benefits of Relationship Lending in a Cross-Country Context: A Meta-Analysis", Management Science, 62(1), pp. $90-110$.

Lusardi, A., and O.S. Mitchell (2011), "Financial Literacy and Retirement Planning in the United States", Journal of Pension Economics and Finance, 10(4), pp. 509-525.

Lymperopoulos, C., I.E. Chaniotakis, and M. Soureli (2006), "The Importance of Service Quality in Bank Selection for Mortgage Loans", Managing Service Quality, 16(4), pp.365-379.

Morgan Stanley (2010), Understanding Strategic Defaults - ABS Insights.

Mylonakis, J. (2007), "A Bank Customer Analysis and Mortgage Services Evaluation: Implications of Market Segmentation Policies", Banks and Bank Systems, 2(3), pp. 157-157.

Puri, M., J. Rocholl, and S. Steffen (2013), "What Kinds of Bank-Client Relationships Matter in Reducing Loan Defaults and Why?", Working paper. 